\title{
The Importance of Motivation Factors on Employee Performance in Kosovo Municipalities
}

\author{
Naim Ismajli, Assistant Lecturer at AAB University, (Corresponding Author) \\ AAB University, Zona Industriale Prishtinë - Fushë Kosovë, 10000 Prishtinë, Kosovo \\ Tel: +381 (0) 38601 019, Mobile:+37744199127; E-mail; naimismajli@yahoo.com
}

Jusuf Zekiri, Assistant Professor at SEE University, Ilindenska nr. 335, 1200 Tetovo

Macedonia, Tel: +389 44356 188; web@ seeu.edu.mk

Ermira Qosja, Assistant Professor at European University,

Bulevardi "Gjergj Fishta", H.1,1023, Tirana, Albania, Tel:+355 42421 806; info@uet.edu.al

Ibrahim Krasniqi, Professor at University for Business and Technology

Lagja Kalabria, n.N 10000 Prishtine, Kosovo

ibrakrasniqi@gmail.com; +37744666217

Accepted: February 03, 2015

Doi:10.5296/ jpag.v5i1.7082 URL: http://dx.doi.org/10.5296/ jpag.v5i1.7082

\begin{abstract}
This study tries to identify the factors that motivate employees as human resources in local government that serve as a basis for increasing the service quality. In this study, a structured questionnaire were used in order to collect data from respondents. The questions get answers from respondents about their motivation regarding their performance assessment within municipalities they work. The data was collected using primary and secondary resources. Secondary data were collected from books, textbooks, online articles, magazines, etc. The analyses of the findings from the study show the importance of motivation that is affected by the process of performance assessment. Setting standards and building evaluation systems help strengthen governance of local authorities. In this way municipalities will improve transparency, accountability, and build a corporate culture in the local government management and a better service to the citizens of those municipalities. From the obtained
\end{abstract}


results, salary of workers, professional advancement and opportunity for promotion appear to be among the most important factors of motivation. The other important factors that the study revealed are work conditions, as well as the evaluation and the objective assessment of performance measurement. The data and results will provide additional information for managers of rural and urban municipalities of the Republic of Kosovo about their drafting strategies for a more efficient management of human resources which will increase the quality of services at the local level and beyond.

Keywords: Human resources management, motivation, standards, performance, employees

\section{Introduction}

Managing human resources is a very important concept because the human factor as a resource can generate the comparative advantages for organizations. So, in today's highly competitive environment, HRM is the key to the success of any organization, and an important resource to be cultivated and managed as a strategy that is required by all the organizations. Measuring performance will be qualitative when performance standards are objective, measurable, realistic, and are transparent to all employees. Standards should be written, stating the conditions and specific measurements that will be used in order to assess performance. The quality of performance measurement has a close connection with the establishment of quality standards. If local authorities succeed in establishing standards of performance that will be objective, measurable, realistic and transparent for all employees, then the quality of performance during service delivery to citizens will be higher.

Reporting and communication affects performance in achieving successful management of human resources in local authorities. This process is critical and important to the successful management of performance, because it directly relates to how unique performance and achievement of objectives are intended by the organization that needs to be communicated to the employees. An institution or organization in order to achieve its goals, it must have at the disposal the necessary resources, and using them very effectively. The available resources for organizations or institutions are: human, financial, physical and information resources (Banfield P \& Rebecca. K., 2012). The human resources compared to other resources in an organization are the most important for a successful performance for any organization.

According to Peter Drucker (2006) as the most valuable asset of the 20th century were production machineries. But the most valuable asset of the 21st century, for all types of organizations are knowledgeable workers and their productivity. So, in a society that moves more quickly, knowledge is the key to its development.

\subsection{Research Problem}

The lack of an objective and realistic assessment of the performance of human resources can have an impact on employee motivation for their achievement of results during their working at the local government in Kosovo. The lack of a standard norms and qualitative assessment of the performance of human resources in local government in Kosovo necessitates a need for 
a study where conclusions and generalizations will be drawn in order to set standards and indicators for an objective assessment which will lead to motivating the local government employees.

\subsection{The Objective of the study}

First of all, the study aims to find out the main factors that have an impact on employees' motivation. The study also aims to analyze how the establishment of a performance evaluation system can create a feeling of security to human resources, where all employees' performances are evaluated according to the same criteria and indicators. Institutions should set targets and standards for the future evaluation of the institution, providing an equitable valuation system.

\subsection{The importance of the study}

This study will try to identify the motivating factors of human resources as a basis for increasing the quality of providing services at local level authorities. It will also help to draw conclusions that identify the factors that will be a key for an objective evaluation of the performance level. Furthermore, it will explain the importance and the effect of human resources about the need of assessment, motivation in order to fulfill their requirements which might lead to better services providing to the society.

\subsection{Research questions and hypothesis}

This study will attempt to analyze the factors that motivate employee performance at the local government authorities in Kosovo. It will also make an effort to respond to the following general questions of this research:

1. What are the motivating factors that have an impact on employee performance at the local municipalities in Kosovo?

2. Are there any norms or standards for evaluating human resources performance at the municipality level?

Moreover, the study will attempt to test the main hypothesis of this paper.

Ha: 1. Motivating factors impact employee performance improvement

\section{Literature review}

Human resource management (HRM) is a relatively new approach to people management in any organization. People are considered a key source in this approach. HRM deals with human dimension in the management of an organization. So organizations through human resources management take care of people, their selection, develop their skills, motivating them to higher levels of achievement and success, as well as ensuring the maintenance of their level of engagement in all important activities. So, human resource management is responsible for maintaining good relations in the organization, and the development of individuals and their integration into institutions. 


\subsection{The Concept of Human Resources}

According to Dessler, G (2013) many experts believe that management includes five functions: planning, organizing, issues that deal with staff, management, and control. In general, these present the process of management functions. Some of the specific activities in each function include:

Planning. Establishing goals and standards, the development of rules, procedures, and plans. Organizing. Delegating work; establishing departments, delegation of authority to subordinates, establishing channels of communication, and coordinating the work. Staffing. Determining what kind of people should be hired, recruiting and selecting employees; training and developing staff, setting performance standards, performance evaluation, counseling workers, and compensating workers.

Leading. Forcing others to do the work, maintaining morale and motivating the staff.

Controlling. Setting standards such as sales quotas, quality standards, or production levels, controlling the actual performance compared with the standard, and taking corrective action where necessary.

Human resources represent the total knowledge, skill, ability, opportunity, creativity, motivation and relationships that an enterprise (company) has. Human resources management is composed of a variety of activities and managerial and organizational tasks that are interrelated to provide the workers with knowledge, skills, interest, motivation, and behavioral ways for achieving current and strategic enterprise objectives.

Personnel Management represents a challenge for managers in this technological era where knowledge and skills interact with each other. Personnel management is more focused on the workforce, mainly directed at organizing workers, finding and training them, compensating and giving bonuses to them, meeting their needs, relying on their work and solving problems which can inflict un satisfaction (Mullins, L. 2002). So, people are considered a key source of any organization. Therefore, all organizations develop human resource management in order to use these resources for the success of the organization.

Thus, HRM is an activity that organizations and companies undertake to recruit, retain, and motivate their employees. In other words, HRM represents a set of policies, programs, and plans that your organization adopts with the aim to make employees work with high capacity. This includes everything from recruitment, selection, to the procedures that determine how workers are treated.

Boxall and Purcell (2011) conceptualize performance as a function of job opportunities (such as knowledge, capabilities, and skills that workers need for the realization of their duties), motivation (benefits that workers seek for their motivation) and organization of work (how work and organizations are structured that enable employees perform better).

\subsection{Defining Human Resources Management}

Human Resource Management (HRM) is a relatively new approach for managing people in 
any organization. People are considered an important source in this approach. This approach is concerned with the human dimension in the management of an organization. Therefore, an organization is a body of people, and the way of recruiting, developing skills, motivating people promoting, are activities that appear to be very crucial and important for the success of any organization. Since the beginning of the modern management theory, the terms used to describe the HRM have included personnel and staff, industrial and employee relations and human resource management (Christine, C \& Carbery, R (2013).

Human resource management is defined as a system of activities and strategies that focus on successful management of employees at all levels of the organization with the sole purpose to achieve organizational goals (Byars \& Rue, 2006). So, workers are human resources of an organization, as well as the most important assets of any organization.

Human resource management focuses on the people in an organization, and is a function of management that deals with hiring, motivating and retaining people in an organization. Human resource management in an organization ensures that human talent and skills are used effectively and efficiently to meet the organizational goals and objectives. Human Resource Management is responsible for maintaining good relations in the organization, and developing individuals to intergrate their and the goals of the organization.

According to Edward B. Philippot (1981) HRM is the functioning of personnel concerned with the procurement, development, compensation, integration and maintaining the personnel of an organization in order to achieve the objectives of the organization. Therefore, personnel management is related to planning, organizing, directing, as well as controlling the performance of these operational functions.

Scott, Clothier and Spriegel (1977) have defined human resource management as part of the management which is responsible for the staff that has to do with a focus on those aspects of the operations that are primarily important for the management. Northcott considers human resource management as an extension of general management, which aims to promote and stimulate each employee to give its full contribution to a business purpose. Human resource management is not something that could be separated from the basic managerial functions. So, HRM is an important component of the broader function of management. French Wendell defines human resource management as recruitment, selection, development, compensation and motivation of human resources by the organization.

According to Dessler (2008) human resource management has to do with policies and practices that include aspects related to human resources from a position of management, including recruitment, screening, training, compensation, and evaluation.

Milkovich and Boudreau (1997) think that human resources management is an integrated series of decisions that govern relations between employers and employees. The quality of these decisions contributes to the ability of organizations and employees to achieve the objectives.

HRM is concerned with the human dimension of management. Since each organization is composed of people, buying their services, developing their skills, motivating them to 
achieve higher levels of performance and to ensure that they continue at the same level of their commitment to the organization for achieving the organizational goal. This is true regardless of the type of organization: i.e. government, business, education, health, recreational, or social action (Decenzo \& Robbins, 1989).

\subsection{Motivation and Human Resources Management}

Human resources is used to see how people are motivated by a number of factors related to one another. Motivated people are those who have made a conscious decision to try considerably to achieve something they appreciate. Individuals differ from each other in what is more valuable to them. There are different ways for motivating people, including the fear of job loss, financial prompt, goals for achievement, as well as the objectives for the organization or groups within the organization. It is argued that every employee will require a different purpose, to have a variety of talents in the completion of their task in the organization. The motivation process begins with identifying the needs of the person. Need is a perceived lack that causes a behavior, which aims to remove this felt deprivation. The need may be physiological, psychological or social.

There are some classical theories in the field of motivation, which have been published in the 50 s of the last century, theories that have inspired modern theories that serve as a base for the latter ones. One of these theories is the traditional view which is based on some of the views from the work of Taylor and from the school of scientific management.

Taylor stands that is management's job to determine the right way, while workers benefit from this approach because is the "right way" and the wage increases as a result of productivity growth (https: //www.goldsmithibs.com/resources). Content theories, like theories of Maslow, Herzberg, Theory X and Y, etc., make efforts to explain specific things that actually motivate individuals in their place of work. These theories focus on identifying the needs of the people that they follow in order to satisfy these needs. These theories emphasize the nature and needs and what motivates.

There is the assumption that all individuals respond in the same way for motivating pressures and therefore there is a better way to motivate everyone. So, these theories provide a list of described normative for managers to follow in an effort to increase productivity.

Process theories, like the theory of Vroom change the emphasis of the need to the goals and the processes by which employees are motivated. They try to explain and describe how people start, that support a behaviour that leads a goal to meet the needs or reduce the internal tension. So, the emphasis is on the actual process of motivation.

Theories of the process also attempt to identify the key variables that explain behavior, but the focus is on the dynamics of how the variables are interrelated in explaining the direction, the extent and the continuity of the effort. The main variables in the process models are incentives, motivation, reinforcement and expectations. 


\section{Research methodology}

This section describes the methodology used in this study. It describes the different methods, and methods chosen for this study. Moreover, this part explains the process of research, design, methods of data collection, sample selection, and ways of analyzing the data. Research is an intensive activity that is based on the work of others and generating new ideas to pursue new questions and answers. Research is a systematic investigation in order to find information to solve the raised issues (J.N. Salkind, 2006). There are many different ways to do research, but all research should involve a sequence of activities. This paper uses a questionnaire as a quantitative method. The main purpose of this papers is to identify the factors that affect the motivation of employees in local government in Kosovo. As dependent variable is the motivation and independent variables we assess the performance of employees in local government in Kosovo. The paper used both types of data, primary and secondary. The primary data was collected through a structured questionnaire. Whereas, secondary data was collected from books, textbooks, online articles, journals, etc.

This study used structured questions in order to collect data from respondents. Questions were supposed to find feelings of respondents about their motivation from the assessment of their performance in local government. Data analysis was done through various statistical tools, through SPSS and Excel.

\section{Data presentation and analyses}

This chapter includes a systematic presentation of data obtained from the survey about staff motivation and their performance evaluation.

\subsection{Descriptive statistics}

A structured questionnaire was sent to 320 respondents, but 292 employed by different municipalities of Kosovo responded to it. Thus, the respondent's rate is about $92 \%$. 
Table. 1 Respondents based on their municipality

\begin{tabular}{|c|c|c|c|c|c|}
\hline \multicolumn{6}{|c|}{ Municipalities } \\
\hline & & Frequence & Percentage & $\begin{array}{c}\text { Valide } \\
\text { Percentage }\end{array}$ & $\begin{array}{l}\text { Cumulative } \\
\text { Percentage }\end{array}$ \\
\hline \multirow[t]{22}{*}{ Valid } & Prishtinë & 21 & 7.2 & 7.2 & 7.2 \\
\hline & Prizren & 19 & 6.5 & 6.5 & 13.7 \\
\hline & Gjilan & 21 & 7.2 & 7.2 & 20.9 \\
\hline & Fushë Kosovë & 16 & 5.5 & 5.5 & 26.4 \\
\hline & Vushtri & 15 & 5.1 & 5.1 & 31.5 \\
\hline & Shtime & 13 & 4.5 & 4.5 & 36.0 \\
\hline & Kaçanik & 13 & 4.5 & 4.5 & 40.4 \\
\hline & Viti & 15 & 5.1 & 5.1 & 45.5 \\
\hline & Deçan & 14 & 4.8 & 4.8 & 50.3 \\
\hline & Dragash & 13 & 4.5 & 4.5 & 54.8 \\
\hline & Ferizaj & 17 & 5.8 & 5.8 & 60.6 \\
\hline & Gjakove & 17 & 5.8 & 5.8 & 66.4 \\
\hline & Kline & 3 & 1.0 & 1.0 & 67.5 \\
\hline & Lipjan & 17 & 5.8 & 5.8 & 73.3 \\
\hline & Skenderaj & 6 & 2.1 & 2.1 & 75.3 \\
\hline & Podujevë & 15 & 5.1 & 5.1 & 80.5 \\
\hline & Rahovec & 15 & 5.1 & 5.1 & 85.6 \\
\hline & Shterpc & 15 & 5.1 & 5.1 & 90.8 \\
\hline & Suharekë & 8 & 2.7 & 2.7 & 93.5 \\
\hline & Mitrovice & 16 & 5.5 & 5.5 & 99.0 \\
\hline & Mamusha & 3 & 1.0 & 1.0 & 100.0 \\
\hline & Total & 292 & 100.0 & 100.0 & \\
\hline
\end{tabular}

Table. 1 shows the number of respondents and the number of municipalities that participated in the survey. The study included a total of 21 rural and urban municipalities of Kosovo territory, and 292 responded the structured questionnaire.

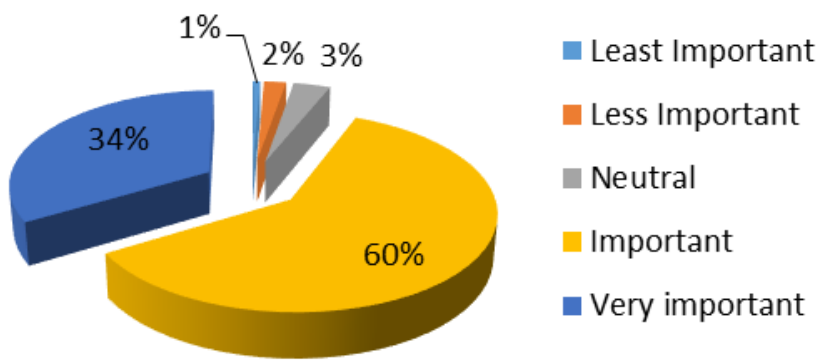

Figure: 1. Work and work conditions 


\section{Macrothink}

From the results obtained and presented in figure: 1 and the distribution of the employees, about 60.3 . \% think work and workplace conditions are important, 34\% very important and $2 \%$ think as less important.

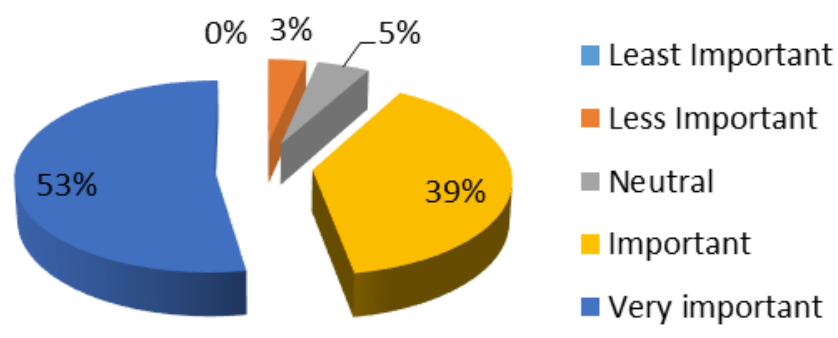

Figure: 2. Salary and its impact on motivation

From the results obtained and presented in figure: 2, the salary and its impact on motivation. From results of employees about $53 \%$ consider salary as a very important factor and $39 \%$ as important, while $3.4 \%$ think it is less important.

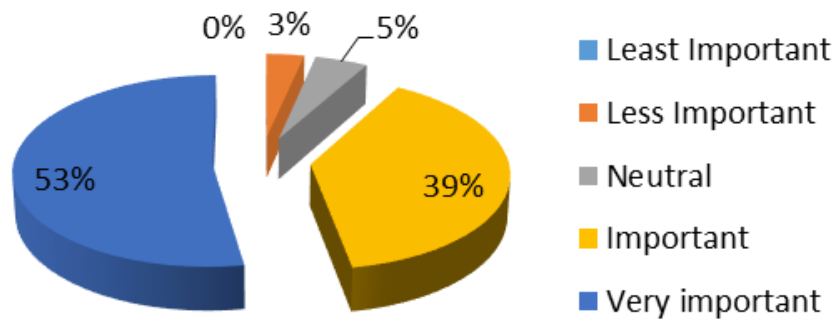

Figure: 3.The importance of professional development

From the results obtained and presented in figure: 2 , the salary and its impact on motivation. From results of employees about $53 \%$ consider salary as a very important factor and $39 \%$ as important, while $3.4 \%$ think it is less important. 

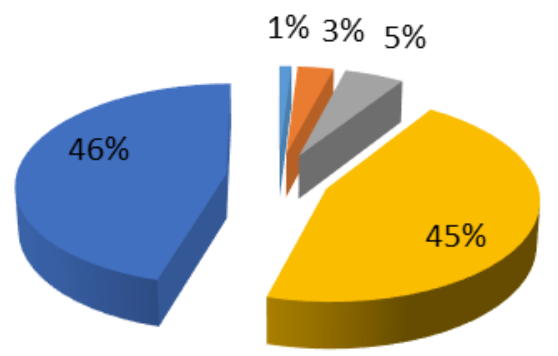

$$
\begin{aligned}
& \text { - Least Important } \\
& \text { - Less Important } \\
& \text { n Neutral } \\
& \text { - Important } \\
& \text { - Very important }
\end{aligned}
$$

Figure: 4.The possibility of using new technology

From the results obtained and presented in figure: 4 , and from the distribution of the employees, about $39 \%$ think the ability to use new technologies is very important, $41 . \%$ as important and $6 \%$ think is less important.

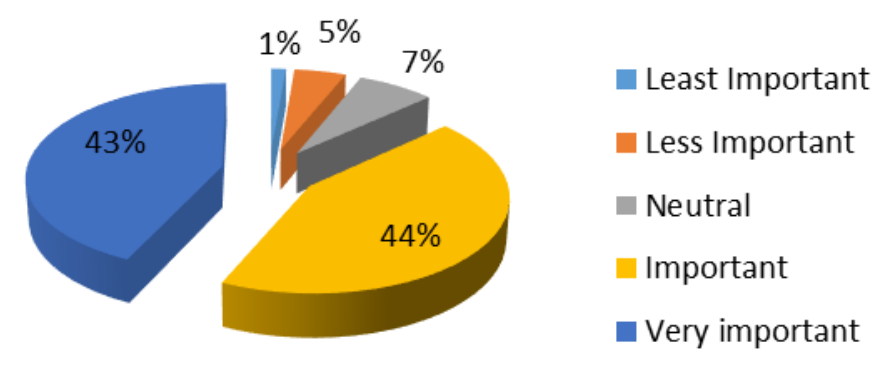

Figure: 5. Permanent trainings for performance improvement

From the results obtained and presented in figure: 5, and the distribution of the employees, about $43 \%$ believe that continuous training about improving performance are very important, $44 \%$ find it important and $5 \%$ think as less important. 


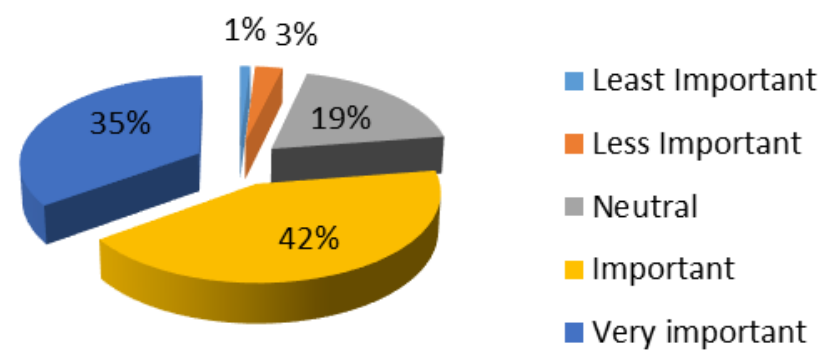

Figure: 6. Relations with the supervisor

From the results obtained and presented in figure: 6, and from the distribution of the employees, about $35 \%$ think that the supervisor reports are very important, $42 . \%$ as important and $3 \%$ think as less important.

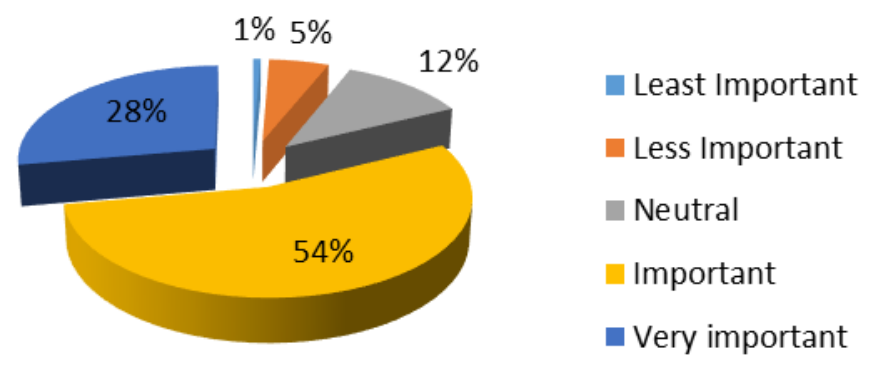

Figure: 7. Evaluation and the just report from performance

From the results obtained and presented in figure: 7, and from the distribution of the employees, about 54.\% think that evaluation and report to measurement of performance is very important, $28 \%$ think as important and about $5 . \%$ as less important. 


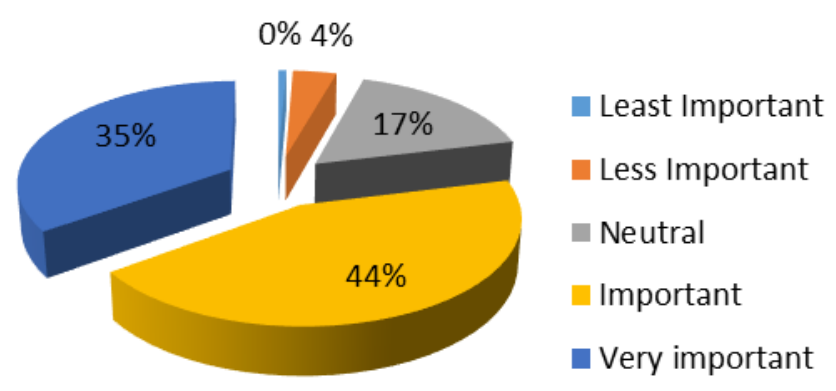

Figure: 8 .The objectivity of procedure for assessing performance

From the results obtained and presented in figure: 8 , about $35 \%$ of the employees think that objectivity about the procedure for measuring the performance is very important, $44 \%$ as important and $4 \%$ think it is less important.

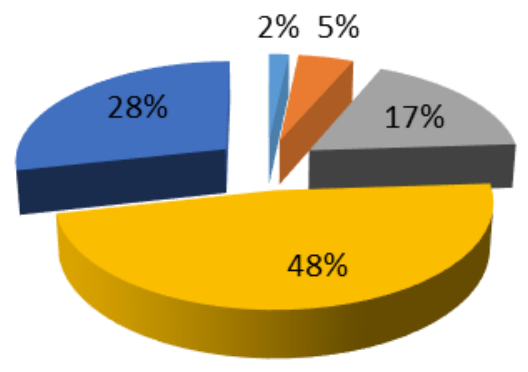

$$
\begin{aligned}
& \text { - Least Important } \\
& \text { - Less Important } \\
& \text { - Neutral } \\
& \text { - Important } \\
& \text { - Very important }
\end{aligned}
$$

Figure: 9. Supervisor's management skills

From the results obtained and presented in figure: 9, from the distribution of the employees, about 28 . \% consider that supervisor's management skills are very important, $48 \%$ as important and 5\% think they are less important. 


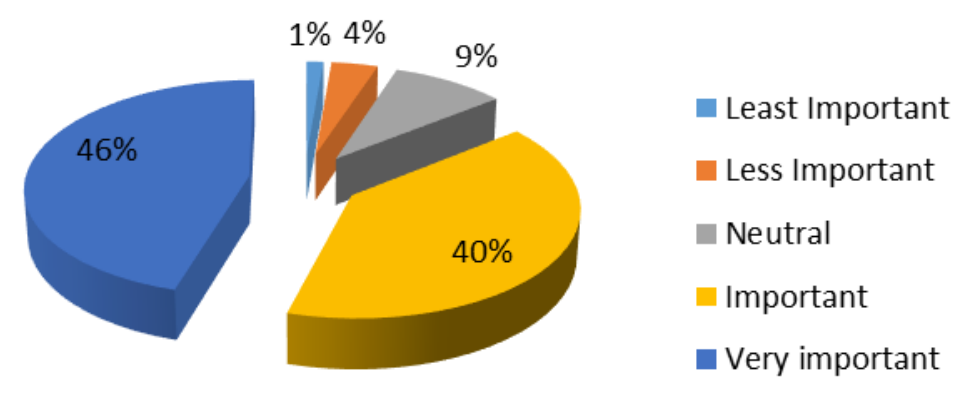

Figure: 10. The ease of promotion

From the results obtained and presented in figure: 10, about $46 \%$ think that the ease of promotion in their career is very important, $40 \%$ important and $4 \%$ think it is less important.

\subsection{Testing the Hypothesis}

The empirical findings should test the following hypothesis.

Null Hypothesis: "There is no relation between motivating factors and performance Improvements"

Alternative Hypothesis: "Motivating factors have an impact on performance improvement" With the null hypothesis, the means are the same, wheras with the alternative hypothesis the means differ. A big " $t$ " $(>+2.0$ or $<-2.0)$, with a small p-value $(<0.05)$, denotes that the null hypothesis is rejected, and we would suppose that the means are significant. But a small " $t$ ", with a big p-value, it denotes that the means are not significantly different. 


\section{Macrothink}

Journal of Public Administration and Governance

ISSN 2161-7104

2015, Vol. 5, No. 1

Table: 2. Motivating factors that have an impact on performance improvement

\begin{tabular}{|c|c|c|c|c|c|c|}
\hline One-Sample Test & & & Test Value $=3$ & & & \\
\hline & & & & & $\begin{array}{l}\text { 95\% Confidence } \\
\text { Interval of the } \\
\text { Difference }\end{array}$ & \\
\hline & $\mathrm{t}$ & df & Sig. (2-tailed) & $\begin{array}{c}\text { Mean } \\
\text { Difference }\end{array}$ & Lower & Upper \\
\hline $\begin{array}{l}\text { Work position and working } \\
\text { condition }\end{array}$ & 31.310 & 291 & .000 & 1.23973 & 1.1618 & 1.3177 \\
\hline $\begin{array}{l}\text { Salary impacts my } \\
\text { motivation on work }\end{array}$ & 32.650 & 291 & .000 & 1.41096 & 1.3259 & 1.4960 \\
\hline $\begin{array}{l}\text { Professional development } \\
\text { importance }\end{array}$ & 28.291 & 291 & .000 & 1.31164 & 1.2204 & 1.4029 \\
\hline $\begin{array}{l}\text { Possibility of using new } \\
\text { technology }\end{array}$ & 22.058 & 291 & .000 & 1.13014 & 1.0293 & 1.2310 \\
\hline $\begin{array}{l}\text { Permanent trainings related } \\
\text { with performance } \\
\text { improvements }\end{array}$ & 23.784 & 291 & .000 & 1.22260 & 1.1214 & 1.3238 \\
\hline $\begin{array}{l}\text { Rapports with the } \\
\text { supervisor }\end{array}$ & 21.411 & 291 & .000 & 1.07534 & .9765 & 1.1742 \\
\hline $\begin{array}{l}\text { The evaluation and the just } \\
\text { for performance measure }\end{array}$ & 21.424 & 291 & .000 & 1.03082 & .9361 & 1.1255 \\
\hline $\begin{array}{l}\text { The objectivity with the } \\
\text { procedure of performance } \\
\text { measure }\end{array}$ & 21.793 & 291 & .000 & 1.08562 & .9876 & 1.1837 \\
\hline $\begin{array}{l}\text { Managerial abilities of the } \\
\text { supervisor }\end{array}$ & 18.315 & 291 & .000 & .96233 & .8589 & 1.0657 \\
\hline $\begin{array}{l}\text { The ease for career } \\
\text { promotion }\end{array}$ & 24.375 & 291 & .000 & 1.24658 & 1.1459 & 1.3472 \\
\hline
\end{tabular}

We can conclude related to results obtained from the table: 2 , that motivation factors affects performance improvement. Furthermore, from the table we can see a big "t" and a small p-value "p". So we can say that the null hypothesis is rejected and the alternative hypothesis is accepted.

\subsection{Validity test -Cronbach Alpha}

Cronbach Alpha was used to compare internal reliability of variables about motivation with the performance assessment. A reliability coefficient of .70 or higher is considered as acceptable in the most research in social sciences. Table: 3 shows Cronbach- alpha based on standardized variables. 
Table: 3. Reliability test

\begin{tabular}{|c|c|c|}
\hline \multicolumn{3}{|l|}{ Reliability statistics } \\
\hline Cronbach's Alpha & $\begin{array}{l}\text { Cronbach's Alpha Based on } \\
\text { Standardized Items }\end{array}$ & $\mathrm{N}$ of Items \\
\hline .954 & .952 & 10 \\
\hline
\end{tabular}

According to table: 3, the results of Cronbach Alpha are .954 for the 10 variables and are above the suggested threshold of .70 . So, results indicate an internal reliability between variables.

Table: 4. ANOVA

\begin{tabular}{|c|c|c|c|c|c|c|}
\hline \multicolumn{7}{|l|}{ ANOVA } \\
\hline & & $\begin{array}{ll}\text { Sum } & \text { of } \\
\text { Squares } & \end{array}$ & df & Mean Square & $\mathrm{F}$ & Sig \\
\hline \multicolumn{2}{|c|}{ Between People } & 4362.154 & 291 & 14.990 & & \\
\hline \multirow[t]{3}{*}{ Within People } & Between Items & 8533.759 & 44 & 193.949 & 280.832 & .000 \\
\hline & Residual & 8842.730 & 12804 & .691 & & \\
\hline & Total & 17376.489 & 12848 & 1.352 & & \\
\hline \multicolumn{2}{|l|}{ Total } & 21738.643 & 13139 & 1.655 & & \\
\hline
\end{tabular}

Table: 4 shows ANOVA used to test the equality of the group average. This tests the changes (variances) of the group. From the results obtained the p-value .000 is less than the significant level of .05. Thus, the lower the p-value is, the less likely the result or null hypothesis to be true, and this results in significant outcome in terms of the statistical significance. Thus, the alternative hypothesis is accepted because the p-value is less than 0.05 or 0.01 . 


\section{Macrothink}

\section{Conclusion}

The data and results will provide additional information for managers of rural and urban municipalities of Kosovo about developing their strategies for a more efficient management which will increase the quality of services at the local level. The responsible people of municipalities will have some empirical results which might help them during the preparation of standards for measuring the performance of employees. These data will serve as a basis for designing programs and strategic plans about performance management of human resources as well as their motivation. The study also high lightened some of the most important factors that serve as a real drive for employees to be motivated. Thus, motivated employees are more likely to increase their productivity during service providing.

The study also provides additional information for municipal managers about factors that are very important for motivating their employees in different municipalities of the Republic of Kosovo. The empirical findings suggest that the municipalities need to be careful about factors that affect the motivation of their employees. From the obtained results, salary of workers, professional advancement and opportunity for promotion appear to be the most important factors of motivation. The other important factors that the study revealed are work conditions, as well as the evaluation and the objective assessment of performance measurement.

\section{References}

Boxall and Purcell in their book Strategy and human resource management (Palgrave Macmillan, third edition, 2011

Boyne, G.A. and R. Walker (2004) 'Strategy Content and Public Service Organizations' Journal of Public Administration Research and Theory 14, 231-252

Cooper, D.R and Schindler, P.S. (2003) Business Research Methods McGraw-Hill: New York, 8 th ed.

Christine Cross and Ronan Carbery (2013) Human Resources Management, Palgrave Macmillan

Decenzo, David A. \& Stephens P. Robbins, 1989, Personnel/HRM, Third Edition, Prentice Hall, New Delhi.

Edwin B. Flippo, Personnel Management, McGraw Hill, 1981

Gary Dessler, 2008 Human Resources Management 11th edition Prentice Hall

Gary Dessler, 2013 Human Resources Management 13th edition Pearson ltd

Laurie,J,Mullins,:’Managment and organizational behavior",Prentice Hall,2002

Milkovich, George T. \& Ë. J. Boudreau, 1997, Human Resource Management, Irëin, Chicago.

Paul Banfield and Rebecca Kay, 2012. Introduction to Human Resources Management, 


\section{Macrothink \\ Journal of Public Administration and Governance ISSN 2161-7104 2015, Vol. 5, No. 1}

Oxford University Press, second edition.

Peter Drucker, 2006 The Practice of Management, Harper Business, Reissue ed., 2006

Scott, Clothier, Spiegel - Personnel Management - Principles, Practices and Point of view, Tata McGraw Hill, New Delhi, 1977

Salkind J.N., (2006) Exploring Research, Pearson Publication, 6th ed.Lawrence, S. et al. (2001). Persistence of Web References in Scientific Research. Computer, 34, 26-31. http://dx.doi.org/10.1109/2.901164 